\title{
NEGARA KITAB SUCI: PEWACANAAN AL-QUR'AN DI JAWA BARAT
}

\author{
Jajang A. Rohmana \\ UIN Sunan Gunung Djati Bandung \\ jajang_abata@yahoo.co.id
}

\author{
Muhamad Zuldin \\ UIN Sunan Gunung Djati Bandung \\ muhd_zuldin@yahoo.co.id
}

\begin{abstract}
This paper focuses on the issue of Qur'anic discourse process in West Java. An important issue related to the efforts of local governments in gaining the support of Muslims through the power of knowledge and hegemony of the scriptural tradition. The power is organized, established and manifested through the knowledge and discourse of the Qur'an that is regulated officially. Through the analysis of hegemony and discursive structures, the study shows that local governments are very interested in controlling and domesticating the interests of Muslims from political forces into the cultural sphere. The local governments are always involved in the process of domestification, as evidenced in strengthening the literacy tradition and facilitating the festival of the Qur'an through the competition and institutional formation. The research confirms that the Qur'an discourse program is part of religious politicization to mark the Islam and Muslim who supports the regime of the ruling local governments.
\end{abstract}




\section{Abstrak}

Artikel ini memfokuskan pada masalah proses pewacanaan al-Qur'an di Jawa Barat. Sebuah isu penting terkait upaya pemerintah daerah dalam meraih dukungan umat Islam melalui kuasa pengetahuan dan hegemoni tradisi kitab suci. Kuasa disusun, dimapankan dan diwujudkan lewat pengetahuan dan wacana al-Qur'an yang diregulasikan dan diresmikan. Melalui analisis hegemoni dan struktur diskursif, studi ini menunjukkan bahwa pemerintahdaerah sangat berkepentingan mengendalikan dan mendomestikasi kepentingan umat Islam dari kekuatan politik ke dalam ruang budaya. Pemerintah daerah selalu terlibat dalam proses domestifikasi tersebut, seperti tampak dalam penguatan tradisi literasi hingga memfasilitasi festivalisasi al-Qur'an melalui perlombaan dan pembentukan kelembagaan. Penelitian ini menegaskan bahwa program pewacanaan al-Qur'an tersebut merupakan bagian dari politisasi keagamaan untuk menandai Islam dan kaum Muslim yang mendukung rezim pemerintah daerah yang berkuasa.

Keywords: al-Qur'an, discourse, local goverments, politics.

\section{A. Introduction}

Dalam tradisi Islam, otoritas agama dan politik kekuasaan sejak lama hampir selalu berjalan beriringan. ${ }^{1}$ Karenanya, alih-alih mengabaikan begitu saja peranan otoritas Islam, penguasa justru menjadikannya sebagai elemen penting dalam menjaga stabilitas pemerintahan. Di Indonesia, pemerintah sejak lama mengakui posisi otoritas Islam itu dalam kehidupan bernegara seperti tampak pada pembentukan berbagai lembaga keagamaan Islam. Di sini, wacana keislaman disosialisasikan melalui program resmi pemerintah. Salah satu program resmi pewacanaan ajaran Islam itu misalnya, cenderung berporos pada pewacanaan al-Qur'an sebagai representasi utama dalam mewadahi kepentingan umat Islam. Ini tercermin dalam berbagai program dan lembaga seperti Musabaqah Tilawatil Qur'an (MTQ), Seleksi Tilawatil Qur'an (STQ), Lembaga Pengembangan Tilawatil Qur'an (LPTQ), Lajnah Pentashih Mushaf al-Qur'an (LPMQ), proyekterjemah dan tafsir al-Qur'an, Rumah Tahfizh, dan lainnya.

Pewacanaan al-Qur'an tersebut mencerminkan apa yang disebut para sarjana sebagai bentuk akomodasi negara atas kepentingan mayoritas

${ }^{1}$ Moch. Nur Ichwan, “Ulama, State and Politics: MUI after Soeharto," Islamic Law and Society, Vol. 12, No. 1, 2005, h. 45-46. 
warganya, khususnya kelompok santri. Pemerintah berusaha "menekan" dengan mendomestikasi kepentingan skisme politik santri. ${ }^{2} \mathrm{Di}$ sini, pemerintah berusaha mendorong agama lebih mengambil peran dalam wilayah sosial-budaya, sehingga menggeser posisi Islam yang semula sebagai kekuatan politik menjadi kekuatan budaya. ${ }^{3}$ Sarjana lain memandang pewacanaan Islam tersebut sebagai bentuk relasi patron-klien pemerintah atas otoritas agama. Negara berusaha menggunakan patronase keagamaan secara luas untuk menjamin loyalitas bawahannya beriringan dengan kekuatan koersifnya yang kuat. ${ }^{4}$ Sebuah campuran bentuk represi dan toleransi, koersi dan kooperasi yang digunakan oleh rezim untuk mengontrol berbagai bentuk perbedaan. ${ }^{5}$

Namun, analisis para sarjana tersebut belum mengungkap sisi lain dari pewacanaan al-Qur'an itu dilihat dari kekuatan hegemoni dan kuasa pengetahuan pemerintah dalam mengatur dan mengendalikan Islam dan kaum Muslim di ruang publik. Ini ditandai oleh simbol-simbol Islam yang lebih mudah terlihat dalam kehidupan sehari-hari. ${ }^{6}$ Sebuah wacana Islam publik yang dibentuk melalui pengetahuan yang diproduksi oleh kekuasaan.

Kajian ini memfokuskan pada proses hegemoni dan kuasa pengetahuan pemerintah tersebut melalui pewacanaan al-Qur'an di Jawa Barat. Sebuah propinsi yang tak jauh dari Jakarta dengan beberapa wilayahnya menjadi satelit bagi ibu kota negara itu dan termasuk paling banyak penduduk Muslimnya. Melalui analisis hegemoni dan struktur diskursif, studi ini berusaha mengungkap faktor kuasa 3 dalam menyusun, memapankan dan mewujudkan hegemoninya melalui pengetahuan dan wacana al-Qur'an yang diregulasikan dan diresmikan di ruang publik. Para

${ }^{2}$ Bahtiar Effendy, Islam and the State in Indonesia, Singapore: Institute of Southeast Asian Studies (ISEAS), 2003, h. 3; Bahtiar Effendy, Islam dan Negara: Transformasi Gagasan dan Praktik Politik Islam di Indonesia, Democracy Project, Yayasan Abad Demokrasi, 2014, h. 25-50;

${ }^{3}$ Robert W. Hefner, "Islamizing Java? Religion and Politics in Rural East Java," The Journal of Asian Studies, Vol. 46, No. 3, 1987, h. 29.

${ }^{4}$ Jamie Mackie, "Patrimonialism: The New Order and Beyond," dalam Edward Aspinall and Greg Fealy ed., Soeharto's New Order and its Legacy, The Australian National University, 2010, h. 82.

${ }^{5}$ Edward Aspinall, Opposing Suharto: Compromise, Resistance, and Regime Change in Indonesia, Stranford California: Stanford University Press, 2005, h. 2.

${ }^{6}$ Sumanto A. Qurtuby, 'Public Islam in Southeast Asia: Late Modernity, Resurgent Religion, and Muslim Politics'. Studia Islamika, 20(3), 2013: 399-442. 
sarjana kritis menyebutnya sebagai bentuk kerja kuasa yang beroperasi tanpa melalui penindasan dan represi, tetapi ada pada normalisasi dan regulasi. ${ }^{7}$ Sebuah bentuk hegemoni budaya sebagai alat yang tanpa paksaan untuk memelihara dominasi penguasa dalam masyarakat. ${ }^{8}$ Kuasa pengetahuan dan hegemoni budaya tersebut misalnya, tampak pada besarnya kepentingan pemerintah dalam proses penguatan tradisi literasi hingga memfasilitasi festivalisasi al-Qur'an melalui perlombaan dan pembentukan kelembagaan. Sebuah upaya politisasi keagamaan dalam rangka menarik dukungan Islam dan kaum Muslim terhadap rezim pemerintah daerah yang berkuasa. Bisa dipahami bila berkat kendali wacana tersebut misalnya, mudah bagi pemerintah Jawa Barat yang berbeda haluan politik nasional dalam konteks pilkada untuk kemudian melakukan politisasi dan mendorong gerakan populisme di daerah-daerah yang menjadi satelit ibu kota terkait isu politik nasional yang melibatkan al-Qur'an jelang pilkada.

\section{B. Hegemoni Negara dan Pelembagaan Keagamaan di Indonesia}

Mayoritas penduduk Indonesia adalah beragama Islam. Jumlahnya sekitar 87.51 persen dari jumlah total penduduk pada sensus tahun 1971 dan meningkat sedikit menjadi 88.22 persen pada tahun $2000 .{ }^{9}$ Posisinya sebagai mayoritas menjadi salah satu faktor yang membuat kaum Muslim cenderung mendominasi wacana keagamaan di Indonesia, salah satunya melalui program pelembagaan Islam yang diresmikan oleh pemerintah.

Pelembagaan keagamaan Islam di berbagai periode pemerintahan tidaklah monolitik. Ia berubah seiring dengan perubahan dinamika pemerintahan dan politik Islam. Di era Soekarno, pendirian Departemen Agama misalnya, tidak bisa dilepaskan dari proses eksperimen demokrasi melalui ideologi Nasakom (nasionalisme, agama dan komunisme). Agama dipandang sebagai unsur mutlak dalam pembangunan bangsa. Soekarno

${ }^{7}$ Eriyanto, Analisis Wacana, Pengantar Analisis Teks Media, (Yogyakarta: LKiS, 2001), h. 66-67; Michel Foucault, Discipline and Punish: The Birth of the Prison, Alan S heridan (trans.), New York: Vintage, 1979, h. 194.

${ }^{8}$ Joseph Francese, ed., Perspectives on Gramsci, Politics, Culture and Social Theory (New York: Routledge, 2009), h. 1.

${ }^{9}$ Leo Suryadinata, Evi Nurvidya Arifin dan Aris Ananta, Indonesia's Population: Ethnicity and Religion in a Changing Political Landscape (Singapore: Institute of Southeast Asian Studies, 2003), h. 104. 
mendukung gagasan "api Islam" dalam melawan apa yang disebutnya sebagai Nekolim (neo-kolonialisme dan imperialisme). ${ }^{10}$

Di era orde Baru (1966-1998), posisi kaum Muslim sebagai mayoritas cenderung dikooptasi negara. Pemerintah saat itu menggunakan slogan 'Islam pembangunan sebagai Islam negara. ${ }^{11}$ Soeharto mengembangkan ideologi pembangunan dan pancasila sebagai asas tunggal. Islam diletakkan dalam kerangka pembangunan. Pelembagaan keagamaan dalam kerangka Islam pembangunan merupakan pemahaman dan praktik Islam yang dibangun dan di fungsionalisasikan ke dalam sebuah lembaga yang digunakan untuk mendukung pembangunan. Lembaga seperti Departemen Agama (Depag), Majelis Ulama Indonesia (MUI), Institut Agama Islam Negeri (IAIN), LPTQ Bank Muamalat Indonesia (BMI), Dewan Masjid Indonesia (DMI), Ikatan Persaudaraan Haji Indonesia (IPHI), Ikatan Cendekiawan Muslim se-Indonesia (ICMI) dan lainnya diwarnai oleh aspek ideologi pembangunan. Pelembagaan keagamaan Islam kiranya bisa didefinisikan sebagai sejenis lembaga Islam yang dibentuk dan atau dipromosikan oleh negara melalui kepentingan dan agenda pembangunan. Bruinessen menyebut pelembagaan tersebut sebagai bagian dari politisasi Islam oleh rezim Soeharto atau dalam bahasa Hefner disebut sebagai "Islam regim" untuk menandai Islam yang mendukung regim negara yang ada. Bahkan ia tidak saja terjadi dalam satu regim, tetapi pelembagaan tersebut berlaku dari satu regim dan berlanjut ke regim berikutnya. ${ }^{12}$

Pada era pasca reformasi 1998, berbagai ekspresi gerakan Islam muncul sebagai respons terhadap tumbangnya rezim Orde Baru. Islam pembangunan berubah ke arah Islam yang jauh lebih ekspresif. Islam semakin menunjukkan vitalitasnya sebagai sistem simbolik dan identitas

${ }^{10}$ B.J. Boland, The Struggle of Islam in Modern Indonesia, Leiden: KITLV, 1971, h. 126; M.C. Ricklefs, A History of Modern Indonesia Since c. 1200, (London: Palgrave, 2001), h. 289.

${ }^{11}$ Moch. Nur Ichwan, "Official Reform of Islam: State Islam and The Ministry of Religious Affairs in Contemporary Indonesia, 1966-2004” Diss, Tilburg University, 2006, h. 3.

${ }^{12}$ Martin van Bruinessen, 'Islamic State or State Islam' Fifty Years of State-Islam Relations in Indonesia', dalam Ingrid Wessel (ed.), Indonesien am Ende des 20. Jahrhunderts (Hamburg: Abera-Verlag, 1996), h. 19-34; Robert W. Hefner, Civil Islam: Muslim and Democratization in Indonesia (Princeton and Oxford: Princeton University Press, 2000), h. 19. 
kolektif yang membentuk dinamika sosial dan politik masyarakat. ${ }^{13}$ Kesadaran keagamaan Muslim Indonesia untuk hidup sesuai dengan nilai dan norma Islam semakin tumbuh. Ini ditandai dengan meningkatnya mobilisasi vertikal kaum santri yang sebelumnya dimarginalisasi. Islam kini tidak lagi berada di pinggiran, tetapi sudah menjadi bagian ekspresi politik, transaksi hukum dan undang-undang, aktifitas ekonomi, dan juga praktik sosial dan budaya.

Berbagai tanda tuntutan Islam politik kiranya bisa dilihat dari munculnya sejumlah partai Islam pasca Soeharto. ${ }^{14}$ Selain itu menguatnya representasi Islam politik juga tampak pada penguatan sejumlah lembaga keagamaan dan penegasan simbol keagamaan di ruang publik. MUI misalnya, cenderung semakin menguat perannya seperti tampak dalam berbagai fatwanya. Habitus kelas menengah Muslim yang berkembang sejak dekade 1990-an semakin berkembang ditandai dengan lebih banyak representasi budaya. ${ }^{15}$ Simbol-simbol Islam seperti tren jilbab juga semakin mendominasi lanskap budaya masyarakat yang mewabah sampai kalangan elit sekalipun. Berbagai lembaga Islam di bidang sosial, ekonomi, pendidikan, media dan kesehatan terus tumbuh. ${ }^{16}$

Penegasan simbol keagamaan di ruang publik juga ditunjukkan oleh semakin maraknya pelembagaan dan pewacanaan al-Qur'an terutama satu dekade terakhir. Wacana menghapal al-Qur'an atau tahfizh misalnya, menjadi salah satu isu yang semakin menguat di berbagai elemen kehidupan masyarakat dibanding sebelumnya. Ini sedikitnya ditunjukkan oleh berkembangnya kegiatan lomba hafalan al-Qur'an, pesantren tahfizh, beasiswa tahfizh, metode cepat menghapal al-Qur'an, one day one juz, training motivasi tahfizh, pencetakan al-Qur'an edisi tahfizh, dan lainnya.

${ }^{13}$ Greg Fealy and Sally White eds., Expressing Islam: Religious Life and Politics in Indonesia, (Singapore: ISEAS, 2008), h. 3.

${ }^{14}$ Anies Rasyied Baswedan, "Political Islam in Indonesia: Present and Future Trajectory,” Asian Survey, XLIV: 5 (2004), h. 672.

${ }^{15}$ Moeflich Hasbullah, "Cultural Presentation of the Muslim Middle Class in Contemporary Indonesia,” Studia Islamika, Vol. 7, No. 2, 2000, h. 2.

${ }^{16}$ Noorhaidi Hasan, "Islamizing Formal Education: Integrated Islamic School and A New Trend in Formal Education Institution in Indonesia," Singapore: Raja ratnam School of International Studies, 2009; Robert W. Hefner, "Islamic Schools, Social Movements, and Democracy in Indonesia," dalam Making Modern Muslims: The Politics of Islamic Education in Southeast Asia, ed. Robert W. Hefner (Honolulu: University of Hawaii Press, 2008); Amelia Fauzia dan Van Der Meij, Dick. ed. Filantropi di Berbagai Tradisi Dunia (CSRC: Jakarta, 2006), h. 10. 
Jawa Barat dikenal sebagai provinsi dengan jumlah penduduk Muslim terbesar di Indonesia. Penganut Muslimnya sekitar 24.01\% atau 42,631,198 dari penduduk Indonesia. ${ }^{17}$ Ia memiliki peranan besar dalam proses pewacanaan al-Qur'an tersebut. Karenanya cukup beralasan bila pemerintah sangat berkepentingan dalam pewacanaan al-Qur'an di Jawa Barat, baik melalui anggaran, infrastruktur maupun program kegiatan di seputar al-Qur'an.

\section{Pelembagaan dan Pewacanaan al-Qur'an di Jawa Barat}

Sebagaimana sudah dijelaskan, Jawa Barat adalah provinsi dengan jumlah penduduk Muslim terbesar di Indonesia. Daerah ini mayoritas dihuni oleh orang Sunda, etnis kedua terbesar setelah Jawa, atau sekitar 15\% dari total penduduk Indonesia. Bagi orang Sunda, mudah mengidentifikasi keislamannya ketika ada identitas kesundaan pada diri mereka. Berbeda dengan daerah lainnya di Jawa, di mana kelompok elitnya cenderung melakukan resistensi terhadap Islam, tetapi di Jawa Barat, kelompok elit justru memperkuat kehadiran Islam. ${ }^{18}$ Pasca runtuhnya Kerajaan Sunda pada 1579, budaya Sunda semakin terbuka dari ragam pengaruh luar seiring dengan hilangnya otoritas keraton sebagai penjaga budaya Sunda dan Islam kemudian mengambil alih peran itu. ${ }^{19}$

Oleh karena itu, kesemarakan Islam di Jawa Barat hingga sekarang hampir tidak bisa dibendung. Di daerah ini, kegiatan keislaman mewarnai seluruh dimensi kehidupan keseharian. Pewacanaan al-Qur'an menjadi salah satu poros penting dalam kesemarakan Islam tersebut di kalangan orang Sunda. Al-Qur'an terus hidup sepanjang waktu (living Qur'an) dan berperan penting dalam ritus peralihan. Sejak mengandung, kelahiran, sunatan, pernikahan, sakit dan kematian hampir selalu diwarnai ritus di seputar al-Qur'an. Di sini bisa dikatakan tradisi besar al-Qur'an yang umumnya dipraktikkan di dunia Muslim dikembangkan secara kreatif ke

${ }^{17}$ Leo Suryadinata, Evi Nurvidya Arifin dan Aris Ananta, Indonesia's Population, h. 109. h. 10-12.

${ }^{18}$ Julian Millie dan Syarif, Dede, Islam dan Regionalisme, (Bandung: Kiblat, 2015),

${ }^{19}$ Julian Millie, Splashed by The Saint: Ritual Reading and Islamic Sanctity in West Java, (Leiden: KITLV Press, 2009), h. 5. 
dalam beragam tradisi kecil al-Qur'an yang khas. ${ }^{20}$ Posisi al-Qur'an yang sudah membudaya membuatnya menjadi budaya generik yang diwariskan dari generasi sebelumnya secara kolektif.. ${ }^{21}$ Tabel berikut menunjukkan bagaimana pewacanaan al-Qur'an secara kultural di Jawa Barat berlangsung dalam bentuk ragam tradisi keagamaan orang Sunda:

\begin{tabular}{cll}
\hline No & \multicolumn{1}{c}{ Bentuk Tradisi } & \multicolumn{1}{c}{ Sumber } \\
\hline 1. & Membacakan al-Qur'an saat mengandung & QS. Yusuf dan Maryam \\
\hline 2. & Memberi nama-nama anak dari al-Qur'an & $\begin{array}{l}\text { Surah Muhammad, } \\
\text { Maryam, Thaha dll. }\end{array}$ \\
\hline 3. & $\begin{array}{l}\text { Mengaji, belajar membaca dan menghapal al- } \\
\text { Qur'an setiap magrib }\end{array}$ & Ayat/surah tertentu \\
\hline 4. & Syukuran setelah khatam al-Qur'an & QS. Al-Fatihah-Al-Nas \\
\hline 5. & $\begin{array}{l}\text { Tradisi khataman al-Qur'an saat acara } \\
\text { sunatan, pernikahan, dll. }\end{array}$ & QS. Al-Fatihah-Al-Nas \\
\hline 6. & $\begin{array}{l}\text { Memperdengarkan bacaan al-Qur'an jelang } \\
\text { salat subuh, magrib, isya, dan Jumatan }\end{array}$ & Ayat/surah tertentu \\
\hline 7. & $\begin{array}{l}\text { Pembacaan kalam Ilahi sebagai pembuka } \\
\text { acara pertemuan }\end{array}$ & Ayat/surah tertentu \\
\hline 8. & Membaca surah Yasin setiap malam Jumat & QS. Yasin/36 \\
\hline 9. & Menempelkan ayat kursi di dinding rumah & QS. Al-Baqarah/2:255 \\
\hline 10. & $\begin{array}{l}\text { Bacaan ayat al-Qur'an untuk mengusir setan } \\
\text { dan marabahaya }\end{array}$ & $\begin{array}{l}\text { Ayat Kursi, QS. Al- } \\
\text { Falaq dan Al-Nas }\end{array}$ \\
\hline 11. & Tadarusan setiap malam di bulan Ramadan & Ayat/surah tertentu \\
\hline 12. & $\begin{array}{l}\text { Membaca surah Yasin pada acara tahlil } \\
\text { malam ke-1 hingga 100 hari }\end{array}$ & QS. Yasin/36 \\
\hline 13. & $\begin{array}{l}\text { Tradisi sumun/seperdelapan bagi istri dalam } \\
\text { warisan }\end{array}$ & QS. Al-Nisa/4: 11 \\
\hline 14. & $\begin{array}{l}\text { Mendoakan kebaikan agar mendapat } \\
\text { keberkahan }\end{array}$ & QS. Al-Fatihah \\
\hline & dll. & \\
\hline
\end{tabular}

Tabel 1: Tradisi al-Qur'an di Jawa Barat

${ }^{20}$ Robert Redfield, Peasant Society and Culture, An Anthropological Approach to Civilization, (Chicago: The University of Chicago Press), 1956, h. 70.

${ }^{21}$ Irwan Abdullah, Konstruksi dan Reproduksi Kebudayaan (Yogyakarta: Pustaka Pelajar, 2007), cet. ke-2. 
Melihat begitu pentingnya posisi al-Qur'an dalam keseharian hidup orang Sunda, maka sangat beralasan bila kemudian pelembagaan dan pewacanaan al-Qur'an terus mendapat perhatian besar dari pemerintah. Negara berkepentingan untuk menciptakan masyarakat Jawa Barat yang pandai membaca, menghapal, memahami dan mengamalkan al-Qur'an. Berbagai infrastruktur berkembang pesat di daerah ini, di antaranya Taman Pendidikan al-Qur'an, rumah tahfizh, pesantren al-Qur'an, percetakan mushaf, penerbitan terjemah dan tafsir al-Qur'an dan lainnya. Sejumlah tradisi baru "agama digital" seperti one day one juz (ODOJ) juga mendapat sambutan di kalangan anak muda. ${ }^{22}$ Program al-Qur'an yang dicanangkan pemerintah juga mendapat sambutan luar biasa masyarakat, di antaranya Program Magrib Mengaji, MTQ-STQ, beasiswa tahfizh dari sekolah dasar, menengah hingga perguruan tinggi, lomba tahfizh dan lainnya. Berikut beberapa program kegiatan dan infrastruktur yang menonjol dalam pewacanaan dan pelembagaan al-Qur'an di Jawa Barat:

1. Proyek penerbitan al-Qur'an

Proyek Penerbitan al-Qur'an di Jawa Barat sepenuhnya didanai oleh APBD Propinsi Jawa Barat. Berdasarkan penelusuran penulis, proyek yang terkait dengan al-Qur'an di Jawa Barat-di luar rutinitas kegiatan MTQ, STQ dan pembentukan LPTQ—-terdiri dari beberapa bentuk: 1) Penyusunan terjemah al-Qur'an bahasa Sunda; 2) Penyusunan tafsir bahasa Sunda; dan 3) Penyusunan mushaf Sundawi.

Proyek al-Qur'an bahasa Sunda pertama kali dipublikasikan Pemprov dan Kanwil Depag Jawa Barat adalah Tarjamah al-Qur'an Basa Sunda hasil proyek PELITA 1974-1979. Proyek al-Qur'an pertama di Jawa Barat ini disusun sebanyak tiga jilid. Ia merupakan respon terhadap publikasi Proyek Al-Qur'an dan Terjemahnya Edisi ke-2 atau lebih dikenal dengan Edisi Mukti Ali. Pemerintah melalui Yayasan Penyelenggara Penterjemah/Pentafsir al-Qur'an Departemen Agama RI yang dibentuk H.A. Mukti Ali (1923-2004). Menteri agama pada masa itu, menerbitkan edisi ke-2 sekitar tahun 1974. Penanggung jawab proyek resmi penerjemahan pertama dalam bahasa Sunda ini adalah Gubernur Jawa Barat saat itu, yakni Aang Kunaepi (1922-1999). Ia menjadi Gubernur dari 19751985. Sementara pelaksananya dipimpin oleh K.H. Anwar Musaddad dkk.

${ }^{22}$ Acep Muslim, "Digital Religion and Religious Life in Southeast Asia: The One Day One Juz (ODOJ) Community in Indonesia,” Asiascape: Digital Asia 4 (2017) 33-51. 
Dilihat dari pola sistematikanya, proyek ini merupakan alih bahasa dari $\mathrm{Al}$ Qur'an dan Terjemahnya yang dibuat dan diterbitkan terlebih dahulu itu. ${ }^{23}$

Proyek kedua, yaitu Terjemahan dan Tafsir Al-Qur'an Bahasa Sunda yang dipublikasikan pada 1978. Pemprov dan Kanwil Depag Jawa Barat menerbitkan terjemah dan tafsir tersebut melalui panitia resmi yang dipimpin oleh K.H. Anwar Musaddad dkk. Karya resmi ini kemudian disempurnakan kembali melalui proyek ketiga, yakni Tafsir Al-Qur'an Basa Sunda sebanyak 6 Jilid pada 1981/1982. Karya ini merupakan Proyek Penerbitan Kitab Tafsir Al-Qur'an Bahasa Sunda Jawa Barat yang terhitung begitu lama proses penyusunannya (1981-1990). Dilihat dari pola sistematikanya, karya ini mengikuti Terjemah dan Tafsir Al-Qur'an yang diterbitkan dalam bahasa Indonesia oleh Departemen Agama RI pada waktu sebelumnya. Bahkan bisa dikatakan, merupakan saduran dari tafsir Depag berbahasa Indonesia itu. Secara gagasan, materi tafsirnya sama saja dan hanya beda bahasa saja. Penanggung jawab proyek ini beberapa kali berubah. Dari pihak Pemprov adalah Gubernur Jawa Barat saat itu, Aang Kunaepi kemudian dilanjutkan Yogie S.M (1929-2007) yang menjabat Gubernur dari 1985-1993. ${ }^{24}$

Proyek keempat, Proyek Penerbitan al-Qur'an Mushaf Sundawi Tahun 1995-2000 yang menonjolkan keindahan iluminasi yang berasal dari kekayaan budaya di Tatar Sunda. Al-Qur'an Mushaf Sundawi memerlukan waktu yang amat panjang rupanya. Tahun 1994, gagasan tersebut muncul atas prakarsa Gubernur R. Nuriana (1. 1938) yang menjabat dari 1993-2003. Kemudian mulai digarap selama 1,5 tahun (14 Agustus 1995 hingga 25 Januari 1997) di kota Bandung Jawa Barat. Mushaf Sundawi merupakan penggabungan antara seni kaligrafi yang berbasis kepada al-Qur'an Standar Depag RI dengan kekayaan ragam hias dan budaya Jawa Barat. Proyek ini menyontoh Proyek al-Qur'an sebelumnya terutama Mushaf Istiqlal (19901995)..$^{25}$

\footnotetext{
${ }^{23}$ Moch. Nur Ichwan, “Negara, Kitab Suci dan Politik: Terjemah Resmi Al-Qur'an di Indonesia," dalam Henri Chambert-Loir (peny.), Sadur Sejarah Terjemahan di Indonesia dan Malaysia (Jakarta: KPG, 2009), h. 420-421.

${ }^{24}$ Kanwil Depag Provinsi Jawa Barat, Tafsir Al-Qur'an Basa Sunda, Juz 1-5, (Bandung: Proyek Penerbitan Kitab Tafsir Al-Qur'an Basa Sunda Jawa Barat dicetak CV. Angkasa, 1991), h. vii.

${ }^{25}$ Agus Ahmad Safe'i, "Fenomena Kultural Islam-Sunda," dalam Cik Hasan Bisri dkk., Pergumulan Islam dengan Kebudayaan Lokal di Tatar Sunda (Bandung: Kaki Langit, 2005), 142-3.
} 
Dalam proses penggarapannya, al-Qur'an Mushaf Sundawi melibatkan ahli al-Qur'an, kaligrafer, seniman dan budayawan Sunda. Nama Sundawi digunakan sebagai istilah yang dikaitkan dengan konsep desain dan tatanan iluminasi yang bersumber dari seni budaya dan kekayaan alam Jawa Barat sebagai ide dasar untuk menghiasi setiap halaman mushaf. Misalnya referensi yang berasal dari momolo (hiasan puncak) masjid, motif batik, ukiran mimbar, mihrab dan artefak lainnya dalam kaidah nonantropomorfisme. Jenis motif kedua adalah desain-desain yang bersumber pada sejumlah flora tertentu yang khas Jawa Barat seperti gandaria, patrakomala, padi dan sawah, hanjuang dan sebagainya. ${ }^{26}$

Proyek kelima, Al-Qur'an Miwah Tarjamahna Dina Basa Sunda pada tahun 2002, Ini sebetulnya terjemah Al-Qur'an resmi kedua yang diproduksi Pemprov Jawa Barat sesudah Tarjamah Al-Qur'an Bahasa Sunda hasil proyek PELITA 1974-1979. Karya ini selain didasarkan pada proyek terjamah sebelumnya, juga didasarkan pada Proyek Penerbitan Al-Qur'an Mushaf Sundawi yang menonjolkan keindahan iluminasi yang berasal dari kekayaan budaya di Tatar Sunda sebagaimana di atas. Perkawinan di antara dua karya tersebut kemudian menjelma dalam karya terjemah yang terkesan lux ini. Karya ini diakui merupakan bukti eratnya orang Sunda dengan alQur'an, eratnya antara budaya Sunda dengan wahyu Allah sebagai pedoman masyarakat Islam di Tatar Sunda dalam kehidupan sehari-hari.

Para personalia yang menyusun karya ini ditetapkan berdasarkan SK Gubernur No. 451.05/KEP.666-YANSOS/14 Juli 2005 di bawah pengarah Gubernur Jawa Barat saat itu yakni Danny Setiawan (1. 1945). Sementara forum pakar terdiri dari para ahli tafsir dan ahli bahasa Sunda. ${ }^{27}$ Meski dilihat dari sisi artistik, karya ini jauh berbeda dengan Tarjamah AlQur'an Bahasa Sunda hasil proyek PELITA 1974-1979, tetapi dari sisi terjemah secara umum masih merujuk pada proyek terjemahan sebelumnya. Namun beberapa penyelasaran bahasa Sunda yang lebih halus dilakukan pula, seperti kata wanoja yang mengganti kata istri untuk terjemah nama surah al-Nisa.

${ }^{26}$ Tim Pelaksana Penulisan Al-Qur'an Mushaf Sundawi, Al-Qur'an Al-Karim Mushaf Sundawi, Bandung, 1997, h. 3.

${ }^{27}$ LPTQ Propinsi Jawa Barat Bekerjasama dengan Handam Citamatra Studio, AlQur'an Miwah Tarjamahna Dina Basa Sunda, (Bandung: Kerjasama Pemprov Jabar, MUI, LPTQ, Kanwil Depag, 2002), h. viii-xi. 
Konon sampai riset ini disusun, Pemprov sejak 2011 sedang mempersiapkan proyek lanjutan, yakni penyusunan kembali tafsir Sunda resmi yang tidak jelas kapan rencana tersebut akan dirampungkan. ${ }^{28}$ Sejak era Gubernur Aang Kunaefi (1975-1985), Yogie S.M. (1985-1993), R. Nuriana (1993-2003), Danny Setiawan (2003-2008), hingga Ahmad Heryawan (2008-2013, 2013-2018), setiap gubernur sepertinya berlomba membuat proyek yang terkait dengan al-Qur'an. Sebut saja sebagai proyek monumental politik keagamaan yang terkait dengan umat Islam dan bisa dikenang sejarah.

2. Program dan infrastruktur kompetisi al-Qur'an

Program dan infrastruktur kompetisi al-Qur'an mencakup kegiatan MTQ STQ dan pendirian LPTQ. Sebuah fenomena yang rutin dilaksanakan dan menjadi bagian dari tradisi keagamaan Islam di Indonesia. Ia sudah menjadi bagian dari kebijakan hegemonik negara terhadap umat Islam. ${ }^{29}$ MTQ dan STQ merupakan festival yang memperlombakan (musabaqah) dalam berbagai bidang keilmuan al-Qur'an. Kegiatan MTQ biasanya jauh lebih besar dan kolosal dibanding STQ karena tidak hanya memperlombakan cabang tertentu tetapi semua cabang dan golongan diperlombakan. Selain itu, MTQ dilaksanakan secara berjenjang dari tingkat desa hingga nasional. STQ biasanya hanya dilaksanakan di tingkat propinsi jelang MTQ Nasional.Inilah sebuah fenomena seni dan agama yang berpusat pada identitas budaya dan kebangsaan di Indonesia. Nilai dan praktek Islam diperkuat melalui intensifikasi bacaan dan musikal dalam upaya memberikan kontribusi terhadap pencapaian tujuan pembangunan spiritual. $^{30}$

MTQ awalnya dimulai dari pendirian Jam'iyyatul Qurra WalHuffazh (perhimpunan para pecinta Seni Baca dan Para penghafal alQur'an) oleh Menteri Agama, KH. A. Wahid Hasyim pada tahun 1951. Organisasi ini merupakan badan otonom di bawah organisasi Nahdlatul Ulama (NU). Organisasi ini pula yang merintis MTQ antar pondok pesantren se-Indonesia dalam rangka menyambut Konferensi Islam Asia

28“Diterbitkan, Tafsir Alquran Berbahasa Sunda”, Pikiran Rakyat, 23 Mei 2009.

${ }^{29}$ Syahrullah Iskandar, "MTQ dan Negara: Sebuah Tinjauan Hegemonik," dalam Irwan Abdullah, et.al., Dialektika Teks Suci, Strukturasi Makna Agama dalam Kehidupan Masyarakat, (Yogyakarta: Pustaka Pelajar dan PPs UGM, 2008), h. 243.

${ }^{30}$ Anne K. Rasmussen, "The Qur'ân in Indonesian Daily Life: The Public Project of Musical Oratory," Ethnomusicology, Vol. 45, No. 1 (Winter, 2001), h. 51-52. 
Afrika (KIAA) tahun 1964 di Bandung. Selanjutnya MTQ Nasional pertama diadakan pada 24 Nopember-1 Desember 1968 di Makassar. ${ }^{31}$ Sejak saat itu, MTQ Nasional secara rutin dilaksanakan dua tahun sekali. MTQ Nasional XXVI Tahun 2016 diselenggarakan Lombok NTB. Program MTQ yang dicanangkan pemerintah tersebut kemudian menular pada lembaga lain untuk menyelenggarakan MTQ, seperti MTQ RRI, MTQ Mahasiswa Nasional, MTQTNI-Polri dan lainnya.

Adapun LPTQ merupakan satu-satunya lembaga yang secara khusus dibentuk untuk mengelola kegiatan Musabaqah Tilawatil Qur'an (MTQ) dan Seleksi Tilawatil Qur'an. Lembaga ini dibentuk di masa Orde Baru sekitar tahun 1977 atau sembilan tahun setelah MTQ Nasional pertama kali diadakan. Pendiriannya berdasarkan Keputusan Bersama Menteri Agama dan Menteri Dalam Negeri Nomor 9 Tahun 1977 dan Nomor 151 tahun 1977 tentang Pembentukan dan Struktur Kepengurusan LPTQ. Lalu dikuatkan dengan Keputusan Bersama Menteri Agama dan Menteri Dalam Negeri Nomor 182 A Tahun 1982 dan Nomor 48 Tahun 1982 tentang Usaha Pengembangan Organisasi LPTQ dan Keputusan Menteri Agama Nomor 240 Tahun 1989 tentang Susunan Organisasi dan Tata Kerja Lembaga Pengembangan Tilawatil Qur'an. ${ }^{32}$

Keputusan pemerintah tersebut kemudian selalu dijadikan dasar pembentukan lembaga LPTQ Tingkat Provinsi, Kabupaten, Kecamatan dan Desa secara nasional. LPTQ Jawa Barat dikelola oleh banyak unsur dari pejabat Pemerintah Propinsi, Kanwil Kemenag Jawa Barat, para akademisi UIN Sunan Gunung Djati Bandung dan lainnya. Anggaran sepenuhnya berasal dari APBD Propinsi. Karenanya, politik anggaran dan sumber daya LPTQ tidak lepas dari sinergi di antara berbagai unsur tersebut. ${ }^{33}$

Secara normatif, MTQ dan STQ yang diselenggarakan LPTQ diarahkan sebagai salah satu sarana untuk mewujudkan pengamalan AlQur'an dalam kehidupan sehari-hari. Karenanya berbagai aspek yang

${ }^{31}$ Pedoman Musabaqah Al-Quran 2010, Diterbitkan oleh Lembaga Pengembangan Tilawatil Qur'an (LPTQ) Tingkat Nasional, Diperbanyak oleh LPTQProvinsi Jawa Barat, Tahun 2011, h. 3 .

${ }^{32}$ Silma Mausuli, “Efektifitas Dakwah Lembaga Pengembangan Tilawatil Qur'an (LPTQ) Provinsi DKI Jakarta Melalui Program Musabaqah Tilawati Qur'an (MTQ) Tahun 2009," Skripsi, (Jakarta: UIN Syarif Hidayatullah Jakarta, 2010), h. 45.

${ }^{33}$ Wawancara dengan Badruzzaman M. Yunus, Ketua Harian LPTQ Jawa Barat, di UIN Bandung, 18/10/2017 jam 15.00 . 
memiliki tujuan ke arah tersebut kemudian diperlombakan dalam MTQdan STQ, seperti membaca, menghafal, menulis, memahami, menafsirkan dan menyampaikan tuntunan al-Qur'an. Pelaksanaannya diwujudkan dalam cabang-cabang lomba. Sekarang terdapat tujuh cabang yang diperlombakan (Tilawah al-Qur'an, Hafizh al-Qur'an, Tafsir al-Qur'an, Fahm al-Qur'an, Syarh al-Qur'an, Khath al-Qur'an dan Menulis Ilmiah al-Qur'an). Masingmasing terdiri dari berbagai kategori yang berbeda-beda, baik berdasarkan usia, jumlah juz, kelompok/grup maupun jenis kelamin. ${ }^{34}$ Jumlah tersebut belum termasuk para anggota hakim, panitia pusat dan daerah serta para penggembira dari seluruh Indonesia. Tuan rumah biasanya menyemarakkan kegiatan tersebut dengan acara pawai, pameran, seminar, dan lainnya. Semua biaya sepenuhnya dibebankan kepada anggaran negara baik pemerintah pusat maupun daerah.

Besarnya anggaran dan kepesertaan dalam kegiatan MTQ bisa dirasakan pula di tingkat provinsi. Dalam kegiatan MTQ ke-34 Tingkat Provinsi Jawa Barat Tahun 2014 di Tasikmalaya misalnya, diikuti 1988 peserta dari 26 Kabupaten/Kota se-Jawa Barat. Acara yang diselenggarakan pada 17-23 April 2016 ini dikelola oleh kepanitiaan yang merupakan gabungan pemerintah provinsi dan lokal kabupaten. ${ }^{35}$ Para pejabat pemerintah biasanya berlomba menjaga image (citra) daerah dengan memberikan semangat kepada para kompetitor dengan mengiming-imingi berbagai uang bonus dan umroh atau haji. Layaknya atlet olahraga, para pemain berusaha tampil sebaik-baiknya dengan harapan mendapatkan 'prestasi' sebaik-baiknya.

Tidak sedikit terjadi "bursa transfer" lintas daerah secara sembunyisembunyi atau terang-terangan di antara para peserta unggulan. Pemda yang kaya pendapatan asli daerahnya dan besar anggaran keagamaannya biasanya mudah ditebak akan selalu unggul dibanding daerah lainnya. MTQ di permukaan bisa dikatakan menjadi ajang semarak kegiatan keagamaan dan pengenalan keunggulan daerah terutama tuan rumah, tetapi di dalamnya tersirat upaya festivalisasi dan komodifikasi keagamaan yang mengarah pada

${ }^{34}$ Pedoman Musabaqah Al-Quran 2010, Diterbitkan oleh Lembaga Pengembangan Tilawatil Qur'an (LPTQ) Tingkat Nasional, Diperbanyak oleh LPTQProvinsi Jawa Barat, Tahun 2011, 55-56, 87.

${ }^{35}$ Buku Panduan MTQ Nasional XXVI Tahun 2016 Provinsi Nusa Tenggara Barat, 17-23 April 2016, h. 23. 
apa yang disebut Rudnyckyj sebagai ajang "ekonomi spiritual." ${ }^{36}$ Pemerintah daerah, peserta dan masyarakat secara tidak langsung terlibat dalam transaksi bagi-bagi untung, tidak saja mendorong citra agamis secara lebih luas, tetapi juga mendatangkan keuntungan materil bagi mereka yang terlibat di dalamnya. Meski pemerintah Indonesia mendapatkan banyak keuntungan dari sistem kompetisi al-Qur'an ini, perlombaan yang disponsori negara itu justru memunculkan ketidakhati-hatian dalam mewariskan aspek mistik dari internalisasi firman Tuhan melalui perhatiannya pada sistem hirarki hakim dan penghargaan secara material. ${ }^{37}$

3. Program hapalan al-Qur'an

Tradisi menghapal al-Qur'an mulanya merupakan kegiatan keagamaan yang menandai penyebaran Islam di Indonesia. Ia terkait dengan pengajaran dasar agama Islam sejak dini di setiap keluarga atau lembaga pendidikan seperti pesantren atau rumah tahfizh. Tradisi tahfizh semakin berkembang secara nasional salah satunya terkait dengan MTQ tahun 1981 di Banda Aceh yang menjadikan cabang tahfizh menjadi cabang resmi MTQ. Banyak pesantren al-Qur'an dan rumah tahfizh di Jawa Barat didirikan untuk mempersiapkan kader-kader terbaiknya dalam menghadapi rutinitas ajang STQ dan MTQ tingkat nasional. ${ }^{38}$ Data Kemenag 2004-2005 menunjukkan terdapat sekitar 6.044 pesantren di Indonesia yang memiliki potensi mengembangkan tahfizh al-Qur'an. ${ }^{39}$

Kini menghapal al-Qur'an semakin berkembang dan menjadi program resmi atau unggulan di banyak sekolah pemerintah dan swasta dari taman kanak-kanak, sekolah dasar, menengah hingga perguruan tinggi di Jawa Barat. Di UIN Sunan Gunung Djati Bandung misalnya, selain terdapat "rumah al-Qur'an," terdapat pula jalur beasiswa khusus bagi calon mahasiswa yang hapal al-Qur'an hingga 30 juz. Selain itu, saat ini semua fakultas mewajibkan mahasiswanya untuk hapal minimal satu juz sebelum

${ }^{36}$ Daromir Rudnyckyj, Spiritual Economies: Islam, Globalization, and the Afterlife of Development, Ithaca, NY: Cornell University Press, 2010.

${ }^{37}$ Anne K. Rasmussen, Women, the Recited Qur'an, and Islamic Music in Indonesia (London: University of California Press, 2010), h. 213.

${ }^{38}$ Tim Penyusun, Panduan Tahfizh Al-Qur'an, Pemerintah Propinsi Jawa Barat, 2014.

${ }^{39}$ Muhammad Shohib dan Bunyamin Yusuf Surur eds. Memelihara Kemurnian AlQur'an: Profil Lembaga Tahfiz Al-Qur'an di Nusantara, Jakarta: Lajnah Pentashih Mushaf Al-Qur'an, 2011. 
sidang kelulusan/munaqasyah. ${ }^{40}$ Hal yang kurang lebih sama juga bisa ditemukan di PTN lainnya seperti Unpad, IPB, UPI dan perguruan tinggi lainnya di Jawa Barat. Bahkan pemerintah provinsi juga turut menyediakan beasiswa jalur prestasi hapalan al-Qur'an tersebut di beberapa PTN.

Penjelasan di atas menunjukkan bahwa pemerintah Jawa Barat memiliki peran besar dalam mendorong kegiatan keislaman di ruang publik yang berporos pada al-Qur'an. Tak hanya melalui penerbitan mushaf, terjemah maupun tafsir al-Qur'an berbahasa Sunda, tetapi juga melalui program festivalisasi kompetisi al-Qur'an seperti MTQ dan bantuan terhadap lembaga hapalan al-Qur'an berupa pesantren tahfizh. Pemerintah menggelontorkan anggaran rutin untuk menunjang kegiatan tersebut. Disini menunjukkan bahwa negara berperan penting dalam peningkatan semangat dan praktik keagamaan yang semakin semarak di ruang publik dibanding privat. ${ }^{41}$ Negara juga menyambut proses modernisasi yang tidak selalu beriringan dengan sekularisasi sebagaimana dikhawatirkan banyak kalangan. ${ }^{42}$

\section{Pewacanaan al-Qur'an dan hegemoni pemerintah}

Terdapat beberapa alasan mengapa isu kepentingan ideologi politik negara dalam pewacanaan al-Qur'an ini penting untuk dikemukakan. Pertama, fenomena penguatan infrastruktur dan kegiatan pewacanaan dan pelembagaan al-Qur'an sebagaimana dijelaskan di atas, telah "membudaya" dan terus mengalami perkembangan di hampir semua periode pemerintahan, dari tingkat pusat hingga daerah. Secara historis, sejak awal kemerdekaan berbagai proyek keagamaan melalui Departemen Agama telah dirintis. Hal ini kemudian diikuti oleh kebijakan yang hampir sama di hampir setiap daerah di Indonesia. ${ }^{43}$

Kedua, penguatan infrastruktur dan kegiatan pewacanaan al-Qur'an merupakan salah satu kebijakan negara yang terkait dengan umat Islam. Di masa Orde Baru, Federspiel menyebutnya sebagai bagian dari Rencana

${ }^{40}$ Surat Keputusan Rektor UIN Bandung, No. Un.05/A/KP.06.7/012/2012.

${ }^{41}$ Greg Fealy and Sally White eds., Expressing Islam, h. 3.

${ }^{42}$ Robert W. Hefner, 'Religious Resurgence in Contemporary Asia: Southeast Asian Perspectives on Capitalism, the State, and the New Piety'. The Journal of Asian Studies, 69 (4), 2010: 1031-1047.

${ }^{43}$ Ismail Lubis, Falsifikasi Terjemah Al-Qur'an Departemen Agama Edisi 1990 (Yogyakarta: Tiara Wacana, 2001), h. 135-148. 
Pembangunan Lima tahun (REPELITA) dari pemerintah pusat dan telah dianggap sebagai bukti bahwa negara terlibat dalam menyebarluaskan nilainilai Islam. Ia juga menjadi bukti kuatnya peran Departemen Agama termasuk adanya keterlibatan para sarjana IAIN yang mencerminkan pandangan ideologi "Muslim Nasionalis." ${ }^{44}$

Proyek pewacanaan al-Qur'an yang didanai pemerintah ini secara politis tidak bisa lepas dari upaya hegemoni pemerintah terhadap umat Islam di Indonesia. Hegemoni yang dimaksud adalah dominasi kepentingan pemerintah atas umat Islam dalam kebijakan pewacanaan al-Qur'an secara nasional yang berimbas pula pada pewacanaan serupa di daerah. Istilah hegemoni dalam pemikiran Gramsci (1891-1937) memiliki dua wajah: bermakna dominasi (berkaitan dengan oposisi negara dan masyarakat sipil) atau kadang dilawankan dengan korporasi (ekonomi), sebuah fase sejarah kelompok tertentu di arena sosial politik. ${ }^{45}$ Gramsci menyebutkan bahwa hegemoni beroperasi di bawah kekuasaan kelas terhadap kelas di bawahnya melalui kekerasan maupun persuasi. Ia berada di tengah persetujuanpersetujuan dengan menggunakan kepemimpinan politik dan ideologis. Negara diposisikan sebagai sarana utama untuk menciptakan kekuatan koersif melalui hegemoni ideologis, mempengaruhi secara dominan dan mengontrol institusi-institusi sosial seperti keluarga, agama, pendidikan dan lainnya. ${ }^{46}$

Menghadapi hegemoni kekuasaan tersebut, bukan berarti tidak ada kelompok yang memiliki kesadaran intelektual terhadap hegemoni kekuasaan. Gramsci menyebutnya sebagai kaum intelektual organik. Namun, strategi persuasi kelas penguasa mampu menarik dan mengendalikan wacana kekuasaan dengan balutan isu sosial dan syiar kesalehan. Bahkan tak sedikit akademisi yang ikut andil dan menjadi pelayan dalam proses hegemoni kuasa tersebut. Berkebalikan dengan Gramsci yang menggunakan istilah intelektual organik, Mahdi 'Amil, pemikir Marxis asal

${ }^{44}$ Howard M. Federspiel, Kajian Al-Qur'an di Indonesia, terj. Tajul Arifin (Bandung: Mizan, 1996), h. 143-144.

${ }^{45}$ QuintineHoare \& Geoffrey Nowell Smith, Selections from the Prison Notebooks od Antonio Gramsci (New York: International Publisher, 1992), h. xiv.

${ }^{46}$ Joseph Francese ed., Perspectives on Gramsci, Politics, Culture and Social Theory (New York: Routledge, 2009), h. 10. 
Libanon, menggunakan istilah mercenaryintellectuals bagi para intelektual pelayan kelas dominan dalam kekuasaan. ${ }^{47}$

Pewacanaan al-Qur'an yang dikoordinasikan melalui Pemerintah Pusat dan Kementerian Agama dilihat dari perspektif hegemoni tersebut merupakan bagian dari hegemoni negara atas institusi agama. Di Jawa Barat, sebagaimana sudah dijelaskan, upaya tersebut dilakukan melalui serangkaian program dan infrastruktur yang dikendalikan oleh Kanwil Departeman Agama Jawa Barat sebagai pemegang otoritas kebijakan keagamaan negara di tingkat propinsi yang bekerjasama dengan Pemerintah Propinsi Jawa Barat sebagai penguasa sekaligus pengelola anggaran di daerah ditambah keterlibatan para ulama dan akademisi dalam struktur kelembagaannya. Tujuan hegemoni kekuasaan ini adalah tercapainya kepentingan stabilitas pemerintahan dengan menggunakan isu pewacanaan al-Qur'an. Disini agama memainkan peran besar dalam politik termasuk membantu kelas berkuasa untuk bertahan secara politik. ${ }^{48}$

Upaya hegemoni keagamaan melalui pewacanaan al-Qur'an ini bisa dipahami mengingat posisi umat Islam sebagai kelompok mayoritas di Indonesia yang layak diakomodasi hak sosial-keagamaannya. Sehingga dalam hal ini, proyek pewacanaan al-Qur'an di satu sisi cenderung bermakna politis dalam mempertahankan kekuasaan status quo, di sisi lain berusaha mengakomodasi kepentingan umat Islam. Negara berusaha mengkonstruksi wacana al-Qur'an dalam rangka menegakkan kepatuhan dan harmoni secara massal dalam struktur sosial-keagamaan masyarakat Indonesia. ${ }^{49}$ Dengan kata lain, secara sosiologis, proyek tersebut mencerminkan relasi simbiosis struktural (structural symbiotic) dengan terciptanya kepentingan di antara kedua belah pihak. Inisiatif berdasar keimanan mendorong pemerintah untuk memfasilitasi ketentuan mendanai kegiatan layanan sosial melalui lembaga keagamaan. Tetapi, ia sekaligus juga mencerminkan kepentingan pemerintah atas umat Islam, meski umat Islam sendiri menerimanya sebagai proyek simbolis saja. ${ }^{50}$ Sebuah proyek yang dijadikan sarana politik

${ }^{47}$ Ibrahim M. Abu-Rabi', Contemporary Arab Thought: Studies in Post-1967 Arab Intellectual History, (London: Pluto Press, 2004), h. 321.

${ }^{48}$ Bryan S. Turner, "Introduction" dalam Bryan S. Turner ed., The New Blackwell Companion to the Sociology of Religion (UK: Blackwell Publishing, 2010), h. 10.

${ }^{49}$ Ariel Heryanto, Perlawanan dalam Kepatuhan (Bandung: Mizan, 2000).

${ }^{50}$ Richard L. Wood, Faith in Action, Religion Race and Democratic Organizing in America (Chicago: The University of Chicago Press, 2002), h. 4. 
pemerintah dalam menunjukkan keberhasilan pembangunan keagamaan di Jawa Barat dalam menjaga keharmonisan antara pemerintah sebagai penguasa dan umat Islam di tatar Sunda sebagai mitra pembangunan.

Dalam konteks pewacanaan al-Qur'an tersebut, kiranya terdapat beberapa saluran atau sarana yang ditempuh negara dalam menjaga kepentingannya dan mengendalikan hegemoni kekuasaannya:

1. Anggaran

Kegiatan pewacanaan al-Qur'an di Jawa Barat sepenuhnya dibiayai oleh APBD Propinsi. Setiap tahunnya Pemprop menyediakan anggaran yang tidak sedikit untuk menopang berbagai program dalam kegiatan tersebut. Dengan demikian pewacanaan al-Qur'an di Jawa Barat bagaimanapun tidak bisa berjalan dengan baik tanpa dukungan APBD Propinsi Jawa Barat. Anggaran menjadi salah satu kunci penting bagaimana pemerintah menjalankan operasi hegemoninya dalam menjaga dan memelihara kekuasaannya. LPTQ menjadi salah satu sarana simbolis pemeliharaan kekuasaan atas nama kepedulian pemerintah terhadap umat Islam. ${ }^{51}$ Pemerintah Propinsi melalui anggaran APBD yang dikucurkan mencitrakan dirinya dengan berusaha mengakomodasi kepentingan umat Islam dalam mewujudkan penghayatan dan pengamalan al-Qur'an dalam masyarakat. Pemerintah Propinsi menyadari bahwa kekuatan mayoritas umat Islam di Indonesia harus dikelola secara baik salah satunya dengan cara mengambil hati dengan mengakomodasi kegiatan keagamaan yang bernuansa religius Islam. Anggaran yang dikucurkan pada LPTQ untuk kegiatan MTQ STQ penerbitan mushaf, terjemah dan tafsir, pesantren tahfizh kiranya tidak bisa dilepaskan dari misi tersebut.

Penggunaan anggaran APBD tersebut biasanya digunakan untuk operasional kegiatan tingkat propinsi yang juga melibatkan semua kabupaten dan kotamadya di Jawa Barat. Tetapi, bukan berarti tidak juga mendapatkan anggaran dari lembaga lain seperti Kanwil Kemenag Jawa Barat, BUMN, dan lainnya. Untuk kegiatan MTQ Jawa Barat yang diselenggarakan dua tahun sekali, selain anggaran APBD Propinsi, terdapat pula sumber anggaran dari Kanwil Kemenag Jawa Barat, APBD Kabupaten, BUMN dan lainnya.

Oleh karena itu, misi pemerintah dalam melakukan pengendalian kekuasaan memang diciptakan sekokoh mungkin. Tidak hanya pada tingkat

${ }^{51}$ Syahrullah Iskandar, “MTQ dan Negara: Sebuah Tinjauan Hegemonik,” h. 254. 
pusat secara nasional, tetapi juga diselenggarakan secara berjenjang sampai ke pelosok-pelosok daerah di tingkat desa dan juga menular ke berbagai institusi pemerintah lainnya. Di daerah, meski anggaran untuk kegiatan MTQ sangat kecil, tetapi program tersebut rutin dilaksanakan dan sudah dianggap menjadi agenda resmi keagamaan terutama dalam menyambut peringatan hari besar Islam. Melalui kegiatan ini, pemerintah dengan mudah melakukan apa yang disebut Foucault dengan mendisiplinkan cara pandang dan pengetahuan masyarakat bukan melalui kekuatan fisik atau senjata, tetapi melalui lembaga sosial-keagamaan dan penanaman ideologi pengetahuan dalam mempersepsikan agama dan moral dalam kerangka stabilitas kekuasaan secara nasional. ${ }^{52}$

Selain itu, anggaran tidak hanya menyimpan misi demi kepentingan hegemoni kekuasaan pemerintah atas umat Islam, tetapi pada praktiknya ia juga menjadi penentu prestasi dan keberhasilan pembinaan yang dilakukan oleh LPTQ bukan hanya di tingkat propinsi tetapi semua daerah di Indonesia. Pemerintah pada dasarnya cukup berkepentingan dengan maju mundurnya prestasi yang terkait dengan LPTQ MTQ dan STQ tetapi kepentingan ini mesti dilihat dari konteks sejauh mana prestasi tersebut menunjang stabilitas dalam kerangka penguatan kekuasaan status quo yang dipegangnya. Sudah umum diketahui bahwa besaran anggaran yang bersumber dari APBD untuk pewacanaan Al-Qur'an melalui LPTQ MTQ, $S T Q$ penerbitan al-Qur'an, pembinaan tahfizh cenderung berbeda-beda di setiap daerah. Hal ini sangat ditentukan oleh pendapatan anggaran dan kemauan (good will) kepala daerah masing-masing dalam mengucurkan besaran anggaran tersebut. Bagi daerah dengan APBD berlimpah dan memiliki kemauan meningkatkan prestasi dan prestise MTQ dan STQ, tentu sangat besar anggarannya terutama untuk "membeli" para qari-qari'ah dan hafizh-hafizhah. Tetapi, tidak sedikit daerah yang hanya sekedarnya saja dalam memberikan anggaran yang disesuaikan dengan tingkat kemampuan daerah tersebut. Bahkan banyak qari-qari'ah dan hafizh-hafizhah yang berasal dari daerah dengan anggaran kecil lebih memilih pindah mewakili daerah lain yang menawarkan banyak bonus (umrah, tabungan, dan lainnya) dari kepala daerahnya. Karenanya prestasi MTQ dan STQ daerah yang anggarannya kecil tidak bisa bersaing dengan daerah lainnya.

${ }^{52}$ Michel Foucault, Power/Knowledge, Selected Interviews and Other Writings 1972-1977, (New York: Pantheon Books, 1980), h. 57-58. 
Oleh sebab itu, besar kecilnya anggaran sangat mempengaruhi tingkat pembinaan dan rekrutmen SDM di ajang lomba MTQ dan STQ. Maraknya "bursa transfer" peserta MTQ antar daerah di Indonesia sangat ditentukan oleh besarnya insentif bonus yang ditawarkan oleh suatu daerah. Bila suatu daerah memiliki anggaran besar maka bonus bagi peserta MTQ dan STQ pun akan besar pula. Tak sedikit peserta berprestasi yang akhirnya berpindah untuk membela daerah lain atas nama bonus ini. Ibarat semut, inilah yang akan dikejar oleh semua peserta MTQ dan STQ dari berbagai daerah. $^{53}$

Anggaran memang sangat menentukan dalam kegiatan pewacanaan al-Qur'an oleh pemerintah. Bukan hanya pada tingkat daerah tetapi nasional. Ia sangat berpengaruh pada bonus yang akan diberikan pada peserta. Bonus yang semula untuk memberi penghargaan bagi peserta MTQ dan STQ kemudian bergeser menjadi semacam daya tarik yang memikat peserta untuk menambah pundi-pundi rezekinya. Hukum ekonomi pun tak terhindarkan berlaku di sini. Daerah yang menawarkan bonus haji atau umroh dengan dana melimpah maka akan menjadi target buruan para peserta untuk ikut serta melamar atau direkrut atas nama daerah tersebut. Negara sebetulnya tidak terlalu berkepentingan dengan ajang persaingan dalam kegiatan MTQ dan STQ tersebut. Baginya, yang penting stabilitas sosial keagamaan bisa tercipta melalui kegiatan tersebut. Anggaran yang sudah dikucurkan dianggap menjadi sarana yang cukup efektif untuk mengakomodir kegiatan umat Islam dalam menciptakan stabilitas terlepas dari adanya persaingan bonus dan bursa transfer peserta yang terjadi di lapangan.

\section{Sarana dan Prasarana}

Peran pemerintah dalam menanamkan jaringan kekuasaan melalui pewacanaan al-Qur'an tidak hanya dilakukan dengan mengucurkan anggaran operasional, tetapi juga melalui penyediaan sarana dan prasana fisik bagi keberlangsungan kegiatan tersebut. Salah satunya melalui pembangunan gedung sekretariat LPTQ Jawa Barat dan semua LPTQ Kota/Kabupaten. Bentuk bantuan Pemerintah Propinsi terhadap penyediaan sarana LPTQJawa Barat misalnya, terlihat dari bangunan yang menjadi sekretariat di Jalan Sukamiskin Bandung. Sekretariat LPTQJawa Barat tersebut terdiri dari bangunan utama sebagai kantor, aula, asrama dan

${ }^{53}$ Wawancara dengan Hamdan Lubis, Ketua Harian LPTQ Kabupaten Subang, di Kantor LPTQ Subang, 5/10/2017 jam 10.00. 
masjid. Kegiatan di sekretariat LPTQJawa Barat tersebut biasanya ramai pada saat jelang penyelenggaraan STQ dan MTQ Nasional antara bulan Januari-Maret. ${ }^{54}$

Di mata pemerintah, boleh jadi gedung sekretariat bisa dianggap menjadi simbol kuatnya dominasi kekuasaan dalam menjaga stabilitas keagamaan di masyarakat. Foucault berjasa dalam menganalisis secara tajam dominasi kekuasaan yang tidak lagi diarahkan pada fisik, tetapi pengetahuan dan sarana-sarananya. ${ }^{55}$ Disiplin masyarakat yang diciptakan pemerintah di setiap elemen ranah sosial-keagamaan membentuk keseragaman persepsi tentang pentingnya stabilitas pembangunan moral keagamaan dalam bingkai Pancasila.

Sejak era Orde Baru, bentuk hegemoni melalui infrastruktur LPTQ, MTQ dan STQ dalam mewujudkan ideologi Pancasila dan pembangunan secara kasat mata juga tampak dalam berbagai atributnya yang terdapat dalam papan nama dan gedung LPTQJawa Barat. Dari lambang LPTQyang menggunakan lambang bunga kapas merah persegi lima melambangkan kesejahteraan jasmaniah rohaniah dalam negara berdasarkan Pancasila. Ia digabungkan dengan lambang Islami seperti kubah masjid, Al-Qur'an dan bintang. Di sini, tampak hegemoni pemerintah atas Islam yang menitikberatkan Islam pembangunan yang berideologikan Pancasila. Begitu pun dalam Mars MTQ Nasional ciptaan Agus Sunaryo yang lagunya kerap diperdengarkan dalam ajang MTQNasional hingga daerah sebagai berikut: “Musabaqah Tilawatil Qur'an pancaran Ilahi//Cinta Allah, Nabi dan Negara wajib bagi kita//Limpah ruah bumi Indonesia adil makmur sentausa//Baldatun Tayyibatun wa Rabbun Ghafur pasti terlaksana. ${ }^{56} \mathrm{Kata}$ "cinta Allah, Nabi dan negara" menandai penanaman ideologi yang berpedoman pada ajaran Islam tetapi dalam kerangka negara dan pemerintahan. LPTQ MTQ dan STQ tidak sekedar menjadi kegiatan keagamaan tempat mengekspresikan rasa cinta pada Allah dan Nabi-Nya, tetapi menunjukkan pula kecintaannya pada negara Pancasila.

${ }^{54}$ Wawancara dengan Mualif, Staf LPTQ Jawa Barat, di Kantor LPTQ Jawa Barat, 14/10/2017 jam 13.00).

${ }^{55}$ Michel Foucault, Power/Knowledge, Selected Interviews and Other Writings 1972-1977, (New York: Pantheon Books, 1980).

${ }^{56}$ Buku Panduan MTQ Nasional XXVI Tahun 2016 Provinsi Nusa Tenggara Barat, 17-23 April 2016, h. 47-50. 
Slogan baldatun tayyibatun wa rabbun ghafur (negeri yang baik dengan ampunan Tuhan) yang berasal dari QS. Saba': 15 dalam lagu tersebut dipinjam dalam rangka melakukan legitimasi disiplin pengetahuan oleh pemerintah tersebut. Sebuah masyarakat damai dan tenteram dalam naungan Pancasila dan UUD 1945. Gedung-gedung pemerintah, sekolah, rumah sakit, dan lainnya diciptakan sebagai simbol pembangunan daerah sekaligus kokohnya kontrol pemerintah atas masyarakat itu. Gedung LPTQ Jawa Barat bisa dibaca dalam konteks bagaimana pemerintah menghadirkan dirinya dalam wujud sarana yang membentuk dan mendisiplinkan pengetahuan masyarakat tentang pentingnya wibawa pemerintah dalam menjaga stabilitas dan pembangunan spiritual.

Bagi pengurus LPTQ Jawa Barat dan LPTQ Kabupaten, pembangunan sarana gedung sekretariat LPTQ ini tentu saja sangat terkait dengan persoalan teknis organisasi. Ia sangat diperlukan untuk memperlancar kegiatan pembinaan MTQ di propinsi, kabupaten, kecamatan, dan desa. Sarana kantor diperlukan selain untuk tempat perencanaan dan pembinaan, juga sebagai tempat untuk menyimpan sarana atau alat-alat yang digunakan untuk kegiatan MTQ, STQ dan berbagai arsip penerbitan dan pembinaan dalam pewacanaan al-Qur'an. Ketiadaan sarana sekretariat dianggap menjadi salah satu penghambat kegiatan tersebut. Pembangunan sarana dan prasarana LPTQ Jawa Barat dan LPTQ Kabupaten dilakukan dari mulai proses pengadaan tanah, pembebasan lahan, hingga pembangunan gedung. Semua anggarannya bersumber dari APBD Propinsi atau Kabupaten.

Oleh karena itu, hegemoni pemerintah dalam bidang keagamaan melalui pewacanaan al-Qur'an tampak jelas dalam pembangunan sarana prasarana LPTQ tersebut. Pemerintah berusaha keras untuk memperkokoh pengaruh dan kendalinya melalui pembangunan sarana kesekretariatan ini. Secara politis, ia tidak saja berusaha membangun citra kepedulian pemerintah terhadap umat Islam, tetapi menjadi simbol bagi terciptanya gambaran pemerintah yang religius di mata umat Islam. Gedung LPTQJawa Barat mewakili simbol hegemoni pemerintah yang semakin kuat.

3. Kepengurusan

Selain anggaran dan sarana, bentuk hegemoni pemerintah melalui pewacanaan al-Qur'an ini dilakukan dengan memasok sumber daya manusia (SDM) untuk menduduki jabatan penting dalam keorganisasian LPTQ, MTQ dan STQ. Umumnya SDM ini berasal dari para pejabat Pemda, 
Kemenag dan masyarakat yang berasal dari para mantan birokrat dan ulama. Umumnya pengurus didominasi oleh pejabat pemerintah dibanding ulama dan masyarakat.

Dari susunan sebagian pengurus inti LPTQ Jawa Barat terlihat bahwa dari pejabat tertinggi Pemerintah Propinsi Jawa Barat, yaitu Gubernur, Wakil Gubernur hingga para pejabat di bawahnya seperti Sekretariat Daerah, Asisten Pemerintahan dan Kesejahteraan Rakyat, dan Biro Pelayanan dan Pengembangan Sosial. ${ }^{57}$ Struktur organisasi tersebut juga melibatkan pejabat Kantor Wilayah Kemenag Jawa Barat (Kepala Kanwil, Kepala Bidang Penerangan Agama Islam, Kepala Seksi Pengembangan Musabaqah Al-Qur'an). ${ }^{58}$ Selain itu, struktur pengurus LPTQ Jawa Barat juga melibatkan para ulama, akademisi UIN Sunan Gunung Djati Bandung dan mantan pejabat dan tokoh keagamaan Jawa Barat. Peran Pemerintah Propinsi Jawa Barat sangat dominan di banding unsur lainnya, karena menentukan besaran anggaran, kepengurusan, schedule kegiatan dan lainnya. Kadang beberapa pengurus tidak lagi diikutsertakan dalam kegiatan LPTQ MTQ dan STQ ketika berbeda pandangan dengan pihak propinsi, baik secara politik maupun kepentingan..$^{59} \mathrm{Di}$ sini terlihat bahwa kebijakan pewacanaan al-Qur'an melalui saluran kepengurusan LPTQ MTQ dan STQ tidak steril dari kepentingan politik daerah.

Oleh karena itu, Pemerintah Propinsi dan Kanwil Kemenag Jawa Barat ternyata tidak saja mengendalikan program pewacanaan al-Qur'an melalui kebijakan anggaran dan infrastruktur, tetapi juga ikut mengarahkan kepentingannya melalui saluran kepengurusan atau struktur kelembagaannya, baik PNS aktif, para mantan PNS maupun swasta. Dengan demikian, sebagai penguasa daerah, Pemerintah Propinsi Jawa Barat memiliki otoritas penuh untuk mengendalikan kekuasaannya.

Keterlibatan Pemerintah Propinsi dalam kepengurusan LPTQ, MTQ dan STQ dilakukan secara berjenjang, sebagaimana kepengurusan yang berlaku secara nasional. Dari sisi hegemoni pemerintah, penjenjangan kekuasaan sangat penting dalam mengokohkan jaring-jaring kekuasaan yang merasuk hingga ke daerah. Karenanya, pengendalian kekuasaan akan lebih

${ }^{57}$ www. jabarprov.go.id diakses 16/11/2017 jam 06.08 .

${ }^{58}$ www.jabar.kemenag.go.id diakses 10/11/2017 jam 07.33.

${ }^{59}$ Wawancara dengan Mualif, Staf LPTQ Jawa Barat, di Kantor LPTQJawa Barat, 14/10/2017 jam 13.00). 
mudah dilakukan ketika para pejabat ikut dilibatkan secara berjenjang pula. Pemerintah pusat hanya tinggal mengkomandokan saja kepada unit-unit pemerintah di bawahnya secara instruksional. Pola pengendalian berjenjang dari atas ke bawah (top-down) semacam ini secara struktural dianggap jauh lebih efektif dalam mengorganisasikan program-programnya.

Pemerintah Propinsi Jawa Barat misalnya, ikut mendorong agar seluruh pejabat Kota/Kabupaten dan elemen di bawahnya berpartisipasi dalam kegiatan MTQ Provinsi dan Nasional. Kehadiran pada MTQJawa Barat 2016 di Tasikmalaya misalnya, dihadiri banyak unsur pejabat Kota/Kabupaten, Bupati/Walikota dan wakilnya, Sekretaris Daerah, Asisten Daerah dan para pengurus LPTQ se-Jawa Barat. Begitupun kehadiran para pejabat Pemerintah Propinsi Jawa Barat pada MTQ Nasional 2017 di Nusa Tenggara Barat, dihadiri para pejabat Pemerintah Propinsi Jawa Barat dan Kanwil Jawa Barat dan para pengurus LPTQJawa Barat, karena terdapat peserta MTQ Nasional yang berasal dari Propinsi Jawa Barat. Kehadiran seluruh pejabat dan pengurus tersebut tentu menggunakan anggaran Pemerintah Propinsi. Ia bukan saja mendorong secara psikologis bagi peserta MTQ yang sedang berlomba, tetapi juga berharap memberikan kontribusi materil bagi peserta.

Dengan demikian, sampai di sini kita bisa menyimpulkan bahwa hegemoni pemerintah melalui pewacanaan Al-Qur'an dalam LPTQ MTQ STQ dan program-program lainnya berjalan dengan baik melalui tiga saluran penting, yakni anggaran, sarana dan kepengurusan. Tanpa ketiga hal itu, rasanya sulit pemerintah untuk mengendalikan kebijakannya dalam bidang keagamaan di masyarakat. Terjadi saling ketergantungan antara pemerintah dan umat Islam dalam memandang ketiga saluran tersebut. Di mata pemerintah, ketiganya menjadi sarana efektif dalam memuluskan kepentingan stabilitas keagamaan di masyarakat. Sementara di mata umat Islam, saluran tersebut menunjukkan kepedulian pemerintah dalam mengakomodasi kegiatan bernuansa keagamaan. Kiranya tepat sebagaimana dinyatakan Gramsci bahwa hegemoni pemerintah sudah berlangsung melalui serangkaian proses pembentukan, pemeliharaan dan reproduksi serangkaian makna, ideologi dan praktik kekuasaan di masyarakat melalui saluran anggaran, sarana dan kepengurusan. ${ }^{60}$

${ }^{60}$ David F. Ruccio, "Rethinking Gramsci, Class, globalization, and historical bloc" dalam Joseph Francese ed., Perspectives on Gramsci, Politics, Culture and Social Theory (New York: Routledge, 2009), h. 152-153. 
Pewacanaan al-Qur'an memuluskan upaya tersebut dengan memaknai arti harmoni dan stabilitas pembangunan spiritual di bawah ideologi Pancasila.

Dukungan hegemoni negara tentu saja diterima tanpa reserve oleh pemerintah daerah dan umat Islam, sebab secara politis menjadi kebijakan yang terstruktur secara berjenjang. Ini membuktikan teori Gramsci bahwa kelas penguasa senantiasa berusaha untuk mengendalikan kekuasaan dengan berupaya menghegemoni kelas di bawahnya dengan cara apapun. ${ }^{61}$ Pewacanaan al-Qur'an dibentuk dan diciptakan dalam rangka menciptakan struktur sosial keagamaan yang secara resmi terlembagakan secara berjenjang. Ia menjadi sarana hegemoni kelas penguasa tersebut dalam bidang keagamaan melalui saluran anggaran, sarana dan sumber daya manusia. Sebuah fenomena yang menandai semakin berperannya agama dalam politik, masyarakat dan budaya di era modern, bertentangan dengan asumsi para sarjana terkait kuatnya hubungan antara sekularisasi dan modernisasi. ${ }^{62}$

\section{E. Kesimpulan}

Kajian ini memfokuskan pada masalah proses pewacanaan al-Qur'an di Jawa Barat. Sebuah isu penting terkait upaya pemerintah daerah dalam meraih dukungan umat Islam melalui kuasa pengetahuan dan hegemoni tradisi kitab suci. Kuasa disusun, dimapankan dan diwujudkan lewat pengetahuan dan wacana al-Qur'an yang diregulasikan dan diresmikan. Studi ini menunjukkan bahwa pemerintah daerah sangat berkepentingan mengendalikan dan mendomestikasi kepentingan umat Islam dari kekuatan politik ke dalam ruang budaya. Pemerintah daerah selalu terlibat dalam proses domestifikasi tersebut, seperti tampak dalam penguatan tradisi literasi hingga memfasilitasi festivalisasi al-Qur'an melalui perlombaan dan pembentukan kelembagaan. Penelitian ini menegaskan bahwa program pewacanaan al-Qur'an tersebut merupakan bagian dari politisasi keagamaan untuk menandai Islam dan kaum Muslim yang mendukung rezim pemerintah daerah yang berkuasa. Dalam konteks pewacanaan al-Qur'an di Jawa Barat, upaya hegemoni kuasa tersebut menggunakan saluran anggaran, infrastruktur atau sarana dan kepengurusan. Sebuah bentuk pewacanaan

${ }^{61}$ Chris Barker, The Sage Dictionary of Cultural Studies, (London: Sage Publications, 2004), h. 84.

${ }^{62}$ Bryan S. Turner, "Introduction," h. 10. 
dalam rangka memuluskan dan memaknai arti harmoni dan stabilitas pembangunan. [] 


\section{Daftar Pustaka}

Abdullah, Irwan, Konstruksi dan Reproduksi Kebudayaan, Yogyakarta: Pustaka Pelajar, 2007, cet. ke-2.

Abu-Rabi', Ibrahim M. Contemporary Arab Thought: Studies in Post-1967 Arab Intellectual History, London: Pluto Press, 2004.

Aspinall, Edward, Opposing Suharto: Compromise, Resistance, and Regime Change in Indonesia, Stranford California: Stanford University Press, 2005.

Barker, Chris, The Sage Dictionary of Cultural Studies, London: Sage Publications, 2004.

Baswedan, Anies Rasyied, "Political Islam in Indonesia: Present and Future Trajectory," Asian Survey, XLIV: 5(2004).

Boland, B. J. The Struggle of Islam in Modern Indonesia, Leiden: KITLV, 1971.

Buku Panduan MTQ Nasional XXVI Tahun 2016 Provinsi Nusa Tenggara Barat, 17-23 April 2016.

"Diterbitkan, Tafsir Alquran Berbahasa Sunda", Pikiran Rakyat, 23 Mei 2009.

Effendy, Bahtiar, Islam and the State in Indonesia, Singapore: Institute of Southeast Asian Studies (ISEAS), 2003. . Islam dan Negara: Transformasi Gagasan dan Praktik Politik Islam di Indonesia, Edisi Digital, Democracy Project, Yayasan Abad Demokrasi, 2011.

Eriyanto, Analisis Wacana, Pengantar Analisis Teks Media, Yogyakarta: LKiS, 2001.

Fauzia, Amelia. dan Van Der Meij, Dick. ed. Filantropi di Berbagai Tradisi Dunia (CSRC: Jakarta, 2006).

Fealy, Greg, and Sally White eds., Expressing Islam: Religious Life and Politics in Indonesia, (Singapore: ISEAS, 2008).

Federspiel, Howard M.,Kajian Al-Qur'an di Indonesia, terj. Tajul Arifin (Bandung: Mizan, 1996).

Foucault, Michel, Discipline and Punish: The Birth of the Prison, Alan S heridan (trans.), New York: Vintage, 1979. 
. Power/Knowledge, Selected Interviews and Other Writings 1972-1977, New York: Pantheon Books, 1980.

Francese, Joseph ed., Perspectives on Gramsci, Politics, Culture and Social Theory (New York: Routledge, 2009).

Hasan, Noorhaidi, "Islamizing Formal Education: Integrated Islamic School and A New Trend in Formal Education Institution in Indonesia," Singapore: Rajaratnam School of International Studies, 2009.

Hasbullah, Moeflich. "Cultural Presentation of the Muslim Middle Class in Contemporary Indonesia," Studia Islamika, Vol. 7, No. 2, 2000: 1-58.

Hefner, Robert W., "Islamizing Java? Religion and Politics in Rural East Java," The Journal of Asian Studies, Vol. 46, No. 3, 1987.

. Civil Islam: Muslim and Democratization in Indonesia, Princeton and Oxford: Princeton University Press, 2000.

. "Islamic Schools, Social Movements, and Democracy in Indonesia," dalam Making Modern Muslims: The Politics of Islamic Education in Southeast Asia, ed. Robert W. Hefner, Honolulu: University of Hawaii Press, 2008.

. 'Religious Resurgence in Contemporary Asia: Southeast Asian

Perspectives on Capitalism, the State, and the New Piety'. The Journal of AsianStudies, 69(4), 2010: 1031-1047

Heryanto, Ariel. Perlawanan dalam Kepatuhan, Bandung: Mizan, 2000.

Hoare, Quintine\& Geoffrey Nowell Smith, Selections from the Prison Notebooks od Antonio Gramsci, New York: International Publisher, 1992.

Ichwan, Moch. Nur, "Ulama, State and Politics: MUI after Soeharto," Islamic Law and Society, Vol. 12, No. 1, 2005, h. 45-72.

. "Official Reform of Islam: State Islam and The Ministry of Religious Affairs in Contemporary Indonesia, 1966-2004” Diss, Tilburg University, 2006.

. "Negara, Kitab Suci dan Politik: Terjemah Resmi Al-Qur'an di Indonesia," dalam Henri Chambert-Loir (peny.), Sadur Sejarah Terjemahan di Indonesia dan Malaysia, Jakarta: KPG, 2009.

Iskandar, Syahrullah, "MTQ dan Negara: Sebuah Tinjauan Hegemonik," dalam Irwan Abdullah, et.al., Dialektika Teks Suci, Strukturasi Makna Agama dalam Kehidupan Masyarakat, Yogyakarta: Pustaka Pelajar dan PPs UGM, 2008. 
Kanwil Depag Provinsi Jawa Barat, Tafsir Al-Qur'an Basa Sunda, Juz 1-5, Bandung: Proyek Penerbitan Kitab Tafsir Al-Qur'an Basa Sunda Jawa Barat dicetak CV. Angkasa, 1991.

LPTQ Propinsi Jawa Barat Bekerjasama dengan Handam Citamatra Studio, Al-Qur'an Miwah Tarjamahna Dina Basa Sunda, Bandung: Kerjasama Pemprov Jabar, MUI, LPTQ, Kanwil Depag, 2002.

Lubis, Ismail. Falsifikasi Terjemah Al-Qur'an Departemen Agama Edisi 1990 Yogyakarta: Tiara Wacana, 2001.

Mackie, Jamie. Patrimonialism: The New Order and Beyond, dalam Edward Aspinall and Greg Fealy ed., Soeharto's New Order and its Legacy, The Australian National University, 2010.

Mausuli, Silma, "Efektifitas Dakwah Lembaga Pengembangan Tilawatil Qur'an (LPTQ) Provinsi DKI Jakarta Melalui Program Musabaqah Tilawati Qur'an (MTQ) Tahun 2009," Skripsi, Jakarta: UIN Syarif Hidayatullah Jakarta, 2010.

Millie, Julian. dan Syarif, Dede.Islam dan Regionalisme, Bandung: Kiblat, 2015.

Millie, Julian.Splashed by The Saint: Ritual Reading and Islamic Sanctity in West Java, Leiden: KITLV Press, 2009.

Muslim, Acep. "Digital Religion and Religious Life in Southeast Asia: The One Day One Juz (ODOJ) Community in Indonesia," Asiascape: Digital Asia 4 (2017) 33-51.

Pedoman Musabaqah Al-Quran 2010, Diterbitkan oleh Lembaga Pengembangan Tilawatil Qur'an (LPTQ) Tingkat Nasional, Diperbanyak oleh LPTQ Provinsi Jawa Barat, Tahun 2011.

Qurtuby, Sumanto A. 'Public Islam in Southeast Asia: Late Modernity, Resurgent Religion, and Muslim Politics'. Studia Islamika, 20(3), 2013: 399-442.

Rasmussen, Anne K., Women, the Recited Qur'an, and Islamic Music in Indonesia London: University of California Press, 2010.

. "The Qur'ân in Indonesian Daily Life: The Public Project of Musical Oratory," Ethnomusicology, Vol. 45, No. 1 (Winter, 2001).

Redfield, Robert. Peasant Society and Culture, An Anthropological Approach to Civilization, Chicago: The University of Chicago Press, 1956. 
Ricklefs, M.C. A History of Modern Indonesia Since c. 1200, London: Palgrave, 2001.

Ruccio, David F., "Rethinking Gramsci, Class, globalization, and historical bloc" dalam Joseph Francese ed., Perspectives on Gramsci, Politics, Culture and Social Theory (New York: Routledge, 2009).

Rudnyckyj, Daromir, Spiritual Economies: Islam, Globalization, and the Afterlife of Development, Ithaca, NY: Cornell University Press, 2010.

Safe'i, Agus Ahmad. "Fenomena Kultural Islam-Sunda," dalam Cik Hasan Bisri dkk., Pergumulan Islam dengan Kebudayaan Lokal di Tatar Sunda, Bandung: Kaki Langit, 2005.

Shohib, Muhammad. dan Surur, Bunyamin Yusuf.eds. Memelihara Kemurnian Al-Qur'an: Profil Lembaga Tahfiz Al-Qur'an di Nusantara, Jakarta: Lajnah Pentashih Mushaf Al-Qur'an, 2011.

Surat Keputusan Rektor UIN Bandung, No. Un.05/A/KP.06.7/012/2012 Suryadinata, Leo. Evi Nurvidya Arifin and Aris Ananta, Indonesia's Population: Ethnicity and Religion in a Changing Political Landscape, Singapore: Institute of Southeast Asian Studies, 2003.

Tim Pelaksana Penulisan Al-Qur'an Mushaf Sundawi, Al-Qur'an Al-Karim Mushaf Sundawi, Bandung, 1997.

Tim Penyusun, Panduan Tahfizh Al-Qur'an, Pemerintah Propinsi Jawa Barat, 2014.

Turner, Bryan S., "Introduction" dalam Bryan S. Turner ed., The New Blackwell Companion to the Sociology of Religion, UK: Blackwell Publishing, 2010.

van Bruinessen, Martin, 'Islamic State or State Islam' Fifty Years of StateIslam Relations in Indonesia', dalam Ingrid Wessel (ed.), Indonesien am Ende des 20. Jahrhunderts (Hamburg: Abera-Verlag, 1996).

Wood, Richard L. Faith in Action, Religion Race and Democratic Organizing in America, Chicago: The University of Chicago Press, 2002.

\section{Websites:}

www.jabar.kemenag.go.id diakses 10/11/2017 jam 07.33

www. jabarprov.go.id diakses 16/11/2017 jam 06.08 
Zaprulkhan

Wawancara:

Badruzzaman M. Yunus, Ketua Harian LPTQ Jawa Barat, di UIN Bandung, 18/10/2017 jam 15.00

Hamdan Lubis, Ketua Harian LPTQ Kabupaten Subang, di Kantor LPTQ Subang, 5/10/2017 jam 10.00

Mualif, Staf LPTQJawa Barat, di Kantor LPTQ Jawa Barat, 14/10/2017 jam 13.00). 